\title{
Extraction of DNA from honey and its amplification by PCR for botanical identification
}

\author{
Sona Arun JAIN ${ }^{1 *}$, Flávia Thalita de JESUS ${ }^{1}$, Giulia Manso MARCHIORO ${ }^{1}$, Edílson Divino de ARAÚJO ${ }^{1}$
}

\begin{abstract}
The physiochemical and biological properties of honey are directly associated to its floral origin. Some current commonly used methods for identification of botanical origin of honey involve palynological analysis, chromatographic methods, or direct observation of the bee behavior. However, these methods can be less sensitive and time consuming. DNA-based methods have become popular due to their simplicity, quickness, and reliability. The main objective of this research is to introduce a protocol for the extraction of DNA from honey and demonstrate that the molecular analysis of the extracted DNA can be used for its botanical identification. The original CTAB-based protocol for the extraction of DNA from plants was modified and used in the DNA extraction from honey. DNA extraction was carried out from different honey samples with similar results in each replication. The extracted DNA was amplified by PCR using plant specific primers, confirming that the DNA extracted using the modified protocol is of plant origin and has good quality for analysis of PCR products and that it can be used for botanical identification of honey.
\end{abstract}

Keywords: botanical origin; honey pollen; molecular approach.

\section{Introduction}

Honey is a complex natural substance produced when nectar or sweet secretions from plants surrounding the apiary are collected, modified, and stored in the honeycombs by eusocial bees (BARONI et al., 2009). Honey can be classified as unifloral (when a single plant species is the source of nectar) or multifloral (when honey is a blend of nectar collected from more than one plant species) (MENDES et al., 2009).

Several types of honey have been used for centuries for its nutritional and medical proprieties (VIUDA-MARTOS et al., 2008; FERREIRA et al., 2009; SOCHA et al., 2009; PETERSON; DWYER, 1998; LIBERATO et al., 2013). The chemical constituents and biological properties of honey depend on the nectar source. As a result, honey from different geographical locations with different source of nectar has different nutritional and biological properties (WANG; LI, 2011). Certain plants may produce compounds toxic to humans (KOCA; KOCA, 2007). Therefore, it is important to associate any particular honey with its plant of origin.

There are a number of methods available for the determination of botanical and geographical origins of honey (ANKLAM, 1998). Pollen analysis is traditionally used to determine the geographical origin of honey since pollen reflects the vegetation type from where the nectar has been collected by the bees (SODRÉ et al., 2007; BARTH, 2004). This approach involves the microscopic examination of pollen present in honey, which is a very tiresome process and requires skilled labor, which is rare. Other methods include chemical analysis using chromatographic techniques (STANIMIROVA et al.,
2010) and analysis of the physical and sensory characteristics of the honey (LIBERATO et al., 2013). The chemical constituents of honey may undergo modifications due to time and storage conditions reducing the dependability of these methods of analysis.

With advances in molecular genetics, techniques based on DNA have become the method of choice since they tend to be quick, precise and more reliable. Pollen and other plant-derived components present in honey can serve as the source of DNA, which can be used for the identification of the botanical origin of honey using DNA technology.

DNA extraction from plants poses unique challenges associated with the disruption of plant cell wall and presence of compounds such as tannins, phenols, and complex polysaccharides in the plant cell lysate that can affect DNA quality inhibiting downstream reactions.

CTAB- and SDS-based methods are the two most widely used methods for extracting DNA from plants, These methods involve plant cell lysis by the use of CTAB or SDS followed by DNA purification and DNA precipitation (MOYO et al., 2008; SHARMA; PUROHIT, 2012; FLEISCHMANN; HEUBL, 2009).

In this manuscript, we describe a CTAB-based DNA extraction method as described by Diversity Array Technology (2011), which was successfully modified and utilized for the extraction of DNA from honey. To our knowledge, this is the first report of a DNA extraction from honey. It is also demonstrated that the extracted DNA is enough for PCR amplification and can be used for botanical identification.

Received $7 / 23 / 2013$

Accepted 10/4/2013 (006173)

Department of Biology, Federal University of Sergipe - UFS, Cidade Universitária Prof. José Aloísio de Campo, Av. Marechal Rondon, s/n, Jardim Rosa Elze, CEP 49100-000, São Cristóvão, SE, Brazil,e-mail: sonajain24@yahoo.com

${ }^{*}$ Corresponding author 


\section{Materials and methods}

\subsection{Sample preparation}

The honey samples utilized in this research were collected in the state of Sergipe, Brazil. Three different samples belonging to different apiaries were utilized, and DNA extractions were carried out repeatedly producing the same results. $70 \mathrm{~g}$ of each honey was diluted in $140 \mathrm{~mL}$ of sterilized water and centrifuged at $9500 \mathrm{~g}$ for 20 minutes. The supernatant was discarded, and the sediment containing the pollen and other plant components was utilized for DNA extraction.

\subsection{Reagents and solutions}

The DNA extraction protocol described in this study includes three different stock solutions: Extraction Buffer stock: 0.35M Sorbitol, 0.1M TrisHCl pH 8, and 5mM EDTA pH 8, stored at $4{ }^{\circ} \mathrm{C}$; Lysis Buffer stock: $0.2 \mathrm{M}$ TrisHCl pH 8, 0.05M EDTA pH 8, $2 \mathrm{M} \mathrm{NaCl}$, and $2 \% \mathrm{CTAB}$, stored at $4{ }^{\circ} \mathrm{C}$; and Sarcosyl stock: $5 \%(\mathrm{w} / \mathrm{v})$, stored at room temperature; and also one fresh buffer working solution: $0.5 \%(\mathrm{w} / \mathrm{v})$ Sodiumdisulphite, $2 \%(\mathrm{w} / \mathrm{v})$ PVP-40, 41.7\% (v/v) Extraction buffer stock, 41.7\% (v/v) Lysis Buffer stock, and $16 \%(\mathrm{v} / \mathrm{v})$ Sarcosyl. The fresh working solution is freshly prepared before DNA extraction and can be stored for 4-5 days at room temperature. This solution will separate out into two layers and, therefore, it should be mixed by agitation well before using.

\subsection{DNA extraction}

The sediment obtained after centrifugation of the honey sample was dissolved in $1 \mathrm{~mL}$ of fresh buffer working solution and transferred to a $1.5 \mathrm{~mL}$ microtube. The tubes were incubated in a water bath at $37^{\circ} \mathrm{C}$ overnight and mixed by inverting every 20 minutes for the first 1 to 2 hours. On the next day, $1 \mathrm{~mL}$ of chloroform-isoamyl alcohol was added in the ratio of 24:1, and the tubes were mixed well and slowly for 30 minutes by inversion. The mixture was centrifuged at $4000 \mathrm{~g}$ for 20 minutes, and the water phase was transferred to a fresh tube. Equal volume of ice cold propanol was added to the mixture which was left at $4{ }^{\circ} \mathrm{C}$ overnight. The mixture was then centrifuged at $4000 \mathrm{~g}$ for 30 minutes at room temperature. At this stage, the nucleic acids formed a white precipitate. The supernatant was discarded, and the precipitate was washed with $1 \mathrm{~mL}$ of $70 \%$ ethanol, air dried for 15-20 minutes, and dissolved in $25 \mu \mathrm{l}$ of TE (1M TrisHCl, 0.5M EDTA pH8). The DNA dissolved in TE was stored at $-20{ }^{\circ} \mathrm{C}$. The integrity of the extracted DNA was analyzed by running approximately $5 \mu$ of the extracted DNA on $0.8 \%$ agarose gel, and the gel was visualized after being stained with SYBR green (Sybr Green I, LCG Biotecnologia, Brazil).

\subsection{PCR}

The DNA extracted from $70 \mathrm{~g}$ of honey was diluted $10^{-1}$ times, and $1 \mu \mathrm{l}$ of the diluted sample was used for PCR amplification in $20 \mu \mathrm{l}$ final volume using Taq DNA Pol 2 X Master Mix Red (Ampliqon, Denmark) and plant DNA barcoding primers (CHEN et al., 2010) in $0.5 \mu \mathrm{M}$ final concentration. PCR was performed using the following conditions: $95^{\circ} \mathrm{C} / 5$ minutes followed by 40 cycles of $94^{\circ} \mathrm{C} / 30$ seconds, $55^{\circ} \mathrm{C} / 30$ seconds, 72 ${ }^{\circ} \mathrm{C} / 45$ seconds, and a final extension at $72{ }^{\circ} \mathrm{C} / 10$ minutes. $5 \mu \mathrm{l}$ of PCR product was then run on $1.5 \%$ agarose gel, stained with SYBR green, and visualized under UV light.

\section{Results and discussion}

Honey is produced from plant nectar after being modified by different substances produced by honeybees by dehydration and by maturation in the honeycombs. The original DNA extraction protocol by Diversity Array Technology is meant for DNA extraction from plant, especially fresh samples. It uses CTAB to lyse cells and contains PVP and N-lauroyl sarcosine to remove polyphenols during cell lysis. PVP binds to polyphenolic compounds and can be separated by centrifugation in the chloroform:isoamylalcohol extraction step. N-lauryl sarcosine is used as an antioxidant to prevent the oxidation of polyphenolic compounds during cell lysis which irreversibly binds and damages nucleic acids (FLEISCHMANN; HEUBL, 2009; COUCH; FRITZ, 1990). Two steps of the original protocol were modified in the current research to be utilized for honey from which the DNA is expected to be fragmented and denatured, and there is a small amount of starting material. Firstly, during the cell lysis step, a temperature of $37^{\circ} \mathrm{C}$ was used instead of $65^{\circ} \mathrm{C}$. This was done to reduce the negative impact of high temperature on the already degraded DNA present in the honey. In addition, the incubation time during this step was increased; the original protocol indicated from 1-2 hours, but the protocol proposed in the present study indicates an overnight incubation. This results in a longer incubation time increasing the exposure of the cells with the lysis buffer and hence a more complete cell lysis can be obtained. The second modification was made in the alcohol precipitation step, in which the tubes were incubated at $4{ }^{\circ} \mathrm{C}$ overnight after addition of ice cold propanol instead of just mixing the tubes by inversion after addition of isopropanol. This was carried out also for slow and complete DNA precipitation because DNA with low molecular mass and less concentration is expected to precipitate faster and more easlily under these conditions. Figure 1 shows the gel electrophoresis of the total DNA extracted from three different honey samples (lanes1-3). Total DNA in lane 1 is from honey stored at $4{ }^{\circ} \mathrm{C}$ for a long period of time, and hence it is highly fragmented.

The DNA extracted from the three honey samples including the fragmented DNA, as shown in Figure 1 (lane1), could be easily amplified by PCR (Figure 2) demonstrating that the DNA extraction from honey using the modified protocol proved adequate. Only two reports (VALENTINI; MIQUEL; TABERLET, 2010; LAUBE et al. 2010) utilizing DNA-based methods for analysis of composition and geographical location of honey have been published so far. Both of these reports describe the use of commercial available kits (QiagenGmbH, Hilden, Germany) for DNA extraction from honey. The use of common laboratory reagents for DNA extraction instead of commercially available kits, as described in previous reports, make this extraction process more cost effective.

The choice of primers for PCR is very important during the amplification of DNA from honey, like it occurs with processed food. Due to DNA fragmentation, primers that amplify short 


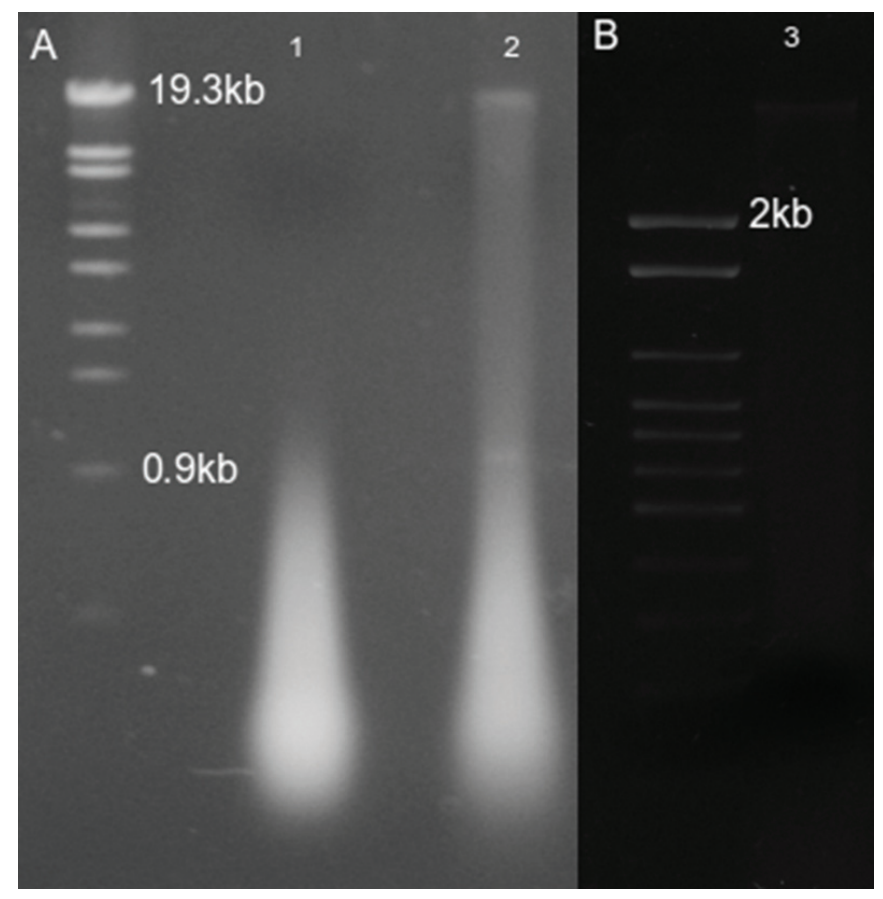

Figure 1. Total DNA extraction from honey.

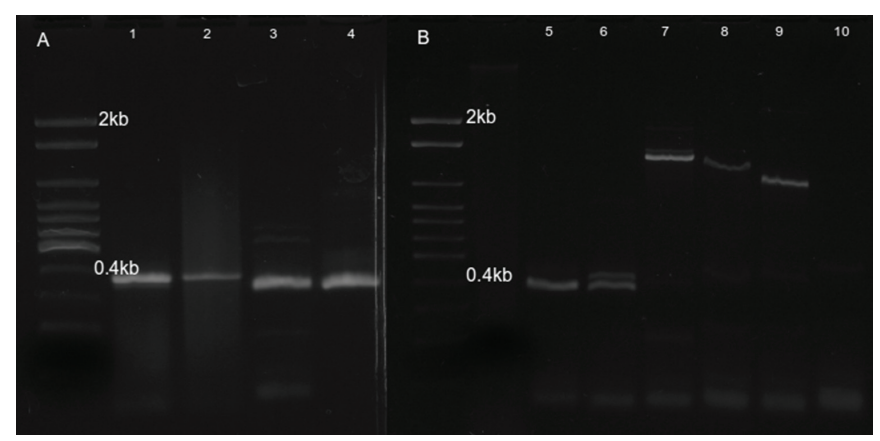

Figure 2. PCR amplification using plant barcoding primers. Lane 1 and lane 6: plant DNA; Lanes 2-5 DNA from honey; lane 7: fungal DNA; lane 8: bacterial DNA; lane 9: DNA from honey bee; lane 10: deionized water.

fragments always work better than those that amplify long fragments (GALIMBERTI et al., 2013). Plant barcoding primers which amplify a region of approximately $0.4 \mathrm{~Kb}$ of rRNA were utilized in this study to amplify total DNA from honey. The PCR band from honey (lanes 2-5) matched in size with the PCR band from plant DNA (lane1 and lane 6), suggesting that the source of this DNA band generated from honey is a plant component present in the honey. Total DNA from bacteria, fungi, and bees were used as controls during PCR analysis to rule out the possibility of the existence of an amplified band from honey corresponding to bacteria, fungi or bee. The amplified DNA from honey after sequencing can be used for a variety of analysis on a molecular level, including identification of its botanical origin and determining the presence or absence of desired plant species. This approach can also be used for the analysis of other apicultural products.

\section{Conclusion}

This study describes for the first time a traditional protocol for the extraction of DNA from honey without the need of a commercial kit. PCR amplification using the extracted DNA from honey as a template confirmed that the extracted DNA is of good quality and can also be used for honey traceability and molecular identification.

\section{Acknowledgements}

The authors are grateful for the financial support provided by the foundations $\mathrm{CNPq}$ (Conselho Nacional de Desenvolvimento Científico e Tecnológico ), Fundação de Apoio à Pesquisa, and Inovação Tecnológica do Estado de Sergipe (FAPITEC-SE).

\section{References}

ANKLAM, E. A review of the analytical methods to determine the geographical and botanical origin of honey. Food Chemistryistry, v. 63 , n. 4 , p. $549-562,1998$. http://dx.doi.org/10.1016/S03088146(98)00057-0

BARONI, M. V. et al. Composition of honey from Córdoba (Argentina) Assessment of North/South provenance by chemometrics. Food Chemistryistry, v. 114 , n. 2, p. 727-733, 2009. http://dx.doi. org/10.1016/j.foodchem.2008.10.018

BARTH, M. O. Melissopalynology in Brazil: a review of pollen analysis of honeys, propolis and pollen loads of bees. Scientia Agricola, v. 61, n. 3, p. 342-350, 2004.

CHEN, S. et al. Validation of the ITS2 region as a novel DNA barcode for identifying medicinal plant species. PLoSONE, v. 5, n. 1, p. e8613, 2010. PMid:20062805 PMCid:PMC2799520. http://dx.doi. org/10.1371/journal.pone.0008613

COUCH, J. A.; FRITZ, P. J. Isolation of DNA from Plants High in Polyphenolics. Plant Molecular Biology Reporter, v. 8, n. 1, p. 8-12, 1990. http://dx.doi.org/10.1007/BF02668875

DIVERSITY ARRAY TECHNOLOGY PTY LTD. Plant DNA extraction protocol for DArT. Disponível em: <http://www. diversityarrays.com/>. Acesso em: 24 June 2011.

FERREIRA, I. C. F. R. et al. Antioxidant activity of Portuguese honey samples: Different contributions of the entire honey and phenolic extract. Food Chemistryistry, v. 114, n. 4, p. 1438-1443, 2009. http://dx.doi.org/10.1016/j.foodchem.2008.11.028

FLEISCHMANN, A.; HEUBL, G. Overcoming DNA extraction problems from carnivorous plants. Anales del Jardín Botánico de Madrid, v. 66, n. 2, p. 209-215, 2009. http://dx.doi.org/10.3989/ ajbm.2198

GALIMBERTI, A. et al. DNA barcoding as a new tool for food traceability. Food Research International, v. 50, n. 1, p. 55-63, 2013. http://dx.doi.org/10.1016/j.foodres.2012.09.036

KOCA, I.; KOCA, A. F. Poisoning by mad honey: A brief review. Food and Chemical Toxicology, v. 45, p. 1315-1318, 2007. PMid:17540490. http://dx.doi.org/10.1016/j.fct.2007.04.006

LAUBE, I. et al. Development of primer and probe sets for the detection of plant species in honey Food Chemistryistry, v. 118, n. 4, p. 979986, 2010.

LIBERATO, M. C. T. C. et al. Physicochemical properties and mineral and protein content of honey samples from Ceará state, Northeastern Brazil. Food Science and Technology, v. 33, n. 1, p. 38-46, 2013. 
MENDES, C. G. et al. As análises de mel: revisão. Revista Caatinga, v. 22 , n. 2, p. 07-14, 2009.

MOYO, M. et al. Optimising DNA isolation for medicinal plants. South African Journal of Botany, v. 74, n. 4, p. 771-775, 2008. http:// dx.doi.org/10.1016/j.sajb.2008.07.001

PETERSON, J.; DWYER, J. Flavonoids: Dietary occurrence and biochemical activity. Nutrition Research, v. 18, n. 12, p. 1995-2018, 1998. http://dx.doi.org/10.1016/S0271-5317(98)00169-9

SHARMA, P.; PUROHIT, S. D. An improved method of DNA isolation from polysaccharide rich leaves of Boswellia serrata Roxb. Indian Journal of Biotechnology, v. 11, p. 67-71, 2012.

SOCHA, R. et al. Antioxidant activity and phenolic composition of herbhoneys. Food Chemistryistry, v. 113, n. 2, p. 568-574, 2009. http://dx.doi.org/10.1016/j.foodchem.2008.08.029

SODRÉ, G. S. et al. Pollen analysis in honey samples from the two main producing regions in the Brazilian northeast. Anais da Academia
Brasileira de Ciências, v. 79, n. 3, p. 381-388, 2007. http://dx.doi. org/10.1590/S0001-37652007000300003

STANIMIROVA, I. et al. Tracing the geographical origin of honeys based on volatile compounds profiles assessment using pattern recognition techniques. Food Chemistryistry, v. 118, n. 1, p. 171176, 2010. http://dx.doi.org/10.1016/j.foodchem.2009.04.079

VALENTINI, A.; MIQUEL, C.; TABERLET, P. DNA barcoding for honey biodiversity. Diversity, v. 2, n. 4, p. 610-617, 2010. http:// dx.doi.org/10.3390/d2040610

VIUDA-MARTOS, M. et al. Functional properties of honey, propolis, and royal jelly. Journal of Food Science, v. 73, n. 9, p. R117-R124, 2008. PMid:19021816. http://dx.doi.org/10.1111/ j.1750-3841.2008.00966.x

WANG, J.; LI, Q. Chemical Composition, Characterization, and Differentiation of Honey Botanical and Geographical Origins. Advances in Food and Nutrition Research, v. 62, p. 89-137, 2011. PMid:21504822. http://dx.doi.org/10.1016/B978-0-12-385989$1.00003-\mathrm{X}$ 